\title{
Pacta Sunt Servanda: Islamic Perception
}

\section{Md Anowar Zahid* \& Rohimi Shapiee**}

Pacta sunt servanda - agreements must be obeyed - is a peremptory principle of modern international law of treaty. What are the origin and nature of this doctrine? Some say, its Latin wording indicates that it is of Roman origin. And this doctrine is a must for the social good; without it the society will be a chaos. But how does Islam perceive the notion? This paper finds that this doctrine came into being with the very beginning of the creation of human souls by Allaah Whom they accepted as their Sole Lord and made a commitment to follow His commands. And it is a principal tenet for Muslims to adhere to because it is an inseparable part of their faith (Iman), a command from their Lord and a practice (Sunnah) of their Prophet Muhammad (peace be upon him). It is, therefore, obligatory not merely because it is good for the society, but is also rooted in the teachings of Islamic doctrine and a Muslim's accountability in the life hereafter.

\section{Keywords}

Pacta Sunt Servanda, Shari'ah, Siyar, Treaty Obligation, Hudaibiyah

\section{Prologue}

The principle of reciprocity is the very backbone of both Siyar and international law. It posits that unilateral acts by any State cannot create a law for another State unless the other State willingly agrees to it either explicitly or implicitly. The reason behind this is that States are sovereign entities which are not subject to any mundane superstate authority. ${ }^{1}$ International treaties are an example of express agreement between States

* Senior Lecturer, Faculty of Law at Universiti Kebangsaan Malaysia (National university of Malaysia). LL.B.(Hon. Dhaka), LL.M.(Dalhousie), Ph.D.(Manchester). The author may be contacted at: dr.anowar.zahid@gmail.com /Address: Faculty of Law, National University of Malaysia, UKM Bangi 43600, Selangor Darul Ehsan, Malaysia.

** Professor, Faculty of Law at Universiti Kebangsaan Malaysia (National university of Malaysia). LL.B (Hon. Malaya), LL.M (Monash), Ph.D. (Manchester). The author may be contacted at: rohimi_s@hotmail.com / Address: Faculty of Law, National University of Malaysia, UKM Bangi 43600, Selangor Darul Ehsan, Malaysia.

1 L. OPPENHEIM, I INTERNATIONAL LAW 119 (H. LAUTERPACHT ED. 1955). 
and international customs are typically an example of their implicit agreement. Both treaties and customs are two important sources of Siyar and international law with one fundamental difference that for Siyar these two sources must be friendly with Shari'ah fountain sources such as the Qur' an and Sunnah. International law is, however, not bound by this qualification because of its secular character. However, it is an interesting question to ask: why should the States obey laws made by treaty or custom? The answer is - because States have agreed to make them. In other words, agreements must be obeyed, which is well-known in Latin terms as pacta sunt servanda. (Popularly known as the pacta doctrine). Though theoretically relevant to both treaties and customs, in practice this doctrine is called into application with respect to treaties.

Over time the pacta doctrine attained the status of an international customary law principle. In the present world it has become a peremptory principle of treaty law, especially by its entrenchment into the Vienna Convention on the Law of Treaties2"every treaty in force is binding upon the parties to it and must be performed in good faith." 3 According to this provision, not only States, also other subjects of international law like multinational companies, which are parties to a treaty or an agreement, must obey it. All jurisdictions of the world have accepted this doctrine because without giving effect to it, treaty obligations cannot be enforced. In the international community, State parties themselves are the chief enforcers of their own responsibility. Why? As said above, because they have bound themselves by giving their consent or promise to the agreement. But a further question may arise- should all promises be kept? The answer depends on what conception of 'promise' or 'agreement' is held. According to common law, all promises (pacta) are not to be kept; only promises that create legal obligations should be kept. ${ }^{4}$ A Civil law system would typically believe that all promises must be kept for social good. 5 What does Islamic law say in this respect? This paper is an attempt to answer this question. This answer is being sought to find a way and means to check the violations of treaties, such as bilateral investment agreements ("BITs"). In the contemporary world BIT violation is ever on rise. In a span of 37 years (1972-2009) there have been 299 disputes filed with the International Centre for the Settlement of Investment Disputes ("ICSID”), an arbitral facility affiliated with the World Bank.6 Of them, 238 have been registered in the last ten years (1999-2009). As of

2 Ian Sinclair, The Vienna Convention on the LaW of Treaties 83 (1984). See also Richard Hyland, Pacta Sunt Servanda: A Meditation, 34 VA. J. INT'L L. 405, 426 (1984).

3 Vienna Convention on the Law of Treaties, art. 26.

Hyland, supra note 2, at 429 .

Id. at $425-426$.

See ICSID, ICSID Cases, available at http://icsid.worldbank.org/ICSID/FrontServlet?requestType=CasesRH \&actionVal=ListCases (last visited on Nov. 5, 2009). 
November 2009, 180 have been settled and 119 are still pending.7 Checking treaty violations requires the pacta doctrine to be taken seriously, which is in turn, a conceptual issue in need of being addressed.

\section{Meaning of Pacta Sunt Servanda in Shari'a}

Surah (Chapter) al-Ma' idah of the Qur' an used the word ' 'aqd' for contract.8 Islamic jurists have given various opinions about the scope of the term. Of them Imam Raghib al-Isfahani's opinion seems to be convincing. According to him, 'aqd includes all kinds of contracts, which he classified as follows: First, Covenant with Allaah to believe in Him, to obey His commands in the way of His prophet. Second, the vow or promise or commitment one takes upon himself or herself. Last, the contract that is made between two persons or two groups or parties or governments. ${ }^{9}$ As such all sorts of contracts Muslim individuals, entities and States are required to fulfill as the Qur' an commands them to fulfill their contracts in the following words: "O those who believe, fulfill the contracts." 10

This is an obligatory command from Allaah, the Lord of the whole universe. This is the very first verse of Surah Ma'idah, which was revealed towards the end of the life of Prophet Muhammad (peace be upon him). About this Surah (and so about the above verse) the Prophet is reported to have said, "Surah Ma'idah is from what has been revealed towards the last stage of the revelation of the Qur' an. So, take what has been made lawful there as lawful for ever and take what has been made unlawful there as unlawful for ever." 11 This means that fulfillment of treaty obligation, which has been made mandatory (fard) in this Surah of the Qur' an, must be obeyed. This command is so important that because of this the whole Surah is also called Surah al-'uqud (Chapter of Promises). 12 Its importance is also understood from the fact that when the Holy Prophet sent Sayyidna 'Amru ibn Hazm as Governor of Yemen, he wrote this verse on the top of the decree of appointment.13 Thus for every Islamic government or State fulfillment of a treaty is a solemn religious duty. This is a special emphasis by Muhammad on the doctrine of pacta in the area of Siyar.

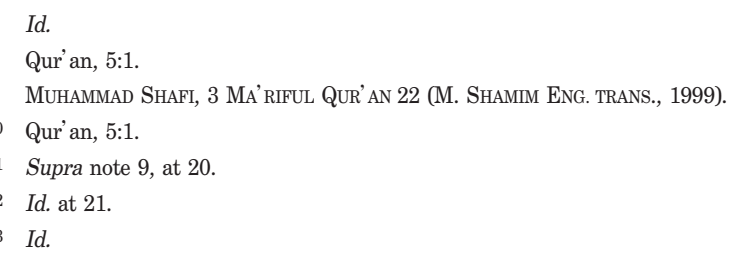




\section{Why Pacta Doctrine in Islam?}

The pacta doctrine is closely and inseparably related to the very existence and purpose of creation of mankind. Allaah created mankind and gathered all souls together in the world of souls ('alam al-arwah) and asked them, "Am I not your Lord (Rabb)?"14 Then all the souls replied, 'Yes indeed.' 15 This was an offer from the Lord of the universe, which mankind did accept. That is why every human being is supposed to have faith in Allaah- to worship only One God. Allaah says,

And why should you not believe in Allaah seeing that the Messenger (Prophet Muhammad) calls on you to believe in your Lord, and He has made a covenant with you (for you to accept faith), if you are believers. 16

After one has accepted the monotheistic faith of Islam and has become a Muslim, it is an obligation for him to keep promises of all sorts. It is unbecoming of him to renege upon them. Rather it is a sign of hypocrisy to do so. In the words of the Prophet, "The signs of a hypocrite are three: whenever he speaks, he tells a lie; whenever he makes a promise, he always breaks it; if you trust him, he proves to be dishonest." 17 That is why Allaah asks the believers to shun this treacherous nature: "And do not make your oaths a deceit to take advantage of one another." 18 Otherwise, they may loose faith (Iman) and turn to be hypocrites: "or else your foot will slip after having been firm (on the path of truth)." 19 And the hypocrites' will end up in the hell: "[S]urely the hypocrites shall be cast into the lowest depth of hell, and you shall find none to help them." 20

Second, Allaah has commanded Muslims to do justice and to be good to others and at the same time to shun indecency, wickedness and transgression (of the limits set by Him). ${ }^{21}$ Qur' an interpreters define justice and being good as follows:

[J]ustice means that one should give the right of the other person in full and take what comes to him, neither less nor more; then, should someone hurt you, you hurt him only as much as he did, no more. And... being good means that you give the

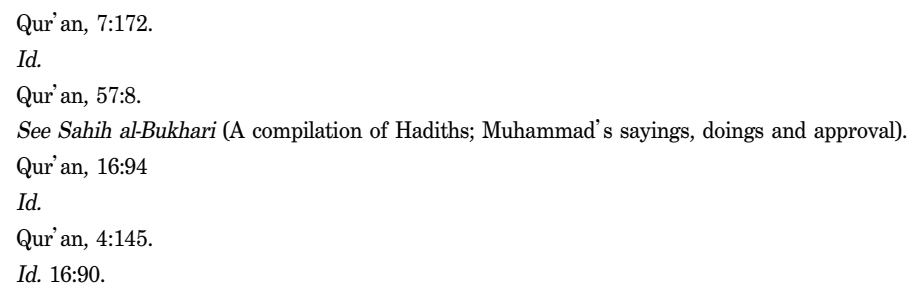


other person more than his real due and, as for your own right, ignore it to the limit that you willingly accept even if it turns out to be less than due. Similarly, when someone hurts you physically or verbally, then, rather than inflicting an equal retaliation against that person you better forgive him, in fact, return the evil done by him with what is good for him. Thus, the command to do justice comes in the form of what is Fard and Wajib (obligatory and necessary as duty) while the command to be good appears in the status of an act which is voluntary (Nafl) and is motivated by a well-meaning desire to contribute more in the way of what is good. 22

Doing justice includes, among other things, keeping promises. ${ }^{23}$ And breaking them is an act of transgression. Therefore, in Shari'ah it is a major sin to break promises or contracts after they have been concluded, which is subject to punishment in the Hereafter.24 According to the Prophet, a flag shall be planted on the back of the pledgebreaker on the Day of Resurrection which will become the cause of his or her disgrace there. ${ }^{25}$ In addition, such a sin must be punished by Allaah in this life as well. The prophet said, there is no sin, except injustice (transgression), the retaliation against which and the punishment for which comes so quickly.26 On the contrary, the victim of the injustice shall be helped by Allaah. ${ }^{27}$ It is also a major sin to act contrary to something that has been sworn by someone. ${ }^{28}$ Allaah says in the Qur' an,

And fulfill the Covenant of Allaah when you pledge, and do not break oaths after you swear them solemnly, while you have made Allaah a witness over you. Surely, Allaah knows all that you do. 29

Sometimes people or States may boast of their economic or military power and may break their treaties in order to earn worldly gains. Allaah has forbidden this.

And do not be like the woman, who has broken her yarn into pieces after spinning it firmly, (by violating agreements that have been sealed) you use your oaths as a means of mischief to snatch at advantages over one another, merely because a group is higher (in number and wealth) than the other. ${ }^{30}$

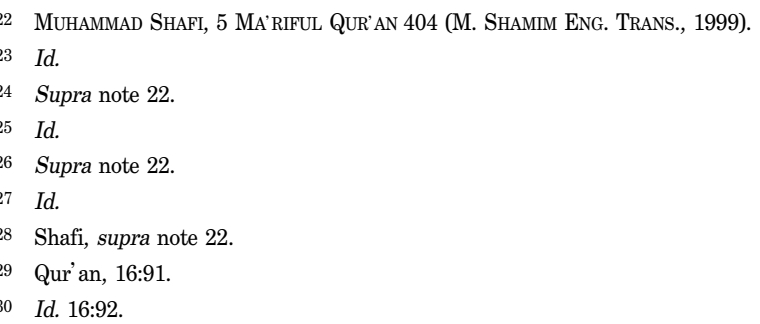


Again, if anything is obligatory for a Muslim (e.g., performing official duties after being employed), it is called Allaah's pledge. 31 That person must carry out his duties without any return or expectation of return from anybody else. On this basis it is forbidden (haram) to take bribes. 32 Such an illegal gain is an ephemeral thing, but the reward which Allaah has promised for keeping the pledge is everlasting. ${ }^{3}$

Thus, Islam has given so much importance to the fulfillment of promises and contracts that Islam has tied it to the very tenet of faith, doing good deeds and rendering justice. In addition, it has made their breaches punishable in both worlds.

\section{Pacta Doctrine in Siyar Practice: Prophet's Examples}

History books abound with examples of keeping promises by the Prophet and his companions in all of their affairs. A few relating to Siyar may be cited in the following:

\section{A. In General: Personal Promises Bearing on Siyar}

\section{Hudhaifah's Case}

Before the commencement of the battle of Badr two prominent companions of the Prophet, Hudhaifah bin al-Yaman and Abu Husail, were going from Makkah to Madina. The people of Makkah stopped them and refused to let them proceed to their destination. On their insistence the Makkans agreed to let them go subject to one condition that they would not participate in the ensuing battle against them. They accepted this condition. On their arrival at Madinah they apprised the Prophet of what happened. The Prophet told them to stay off the battlefield saying that: "[W]e will keep the promise under all circumstances. We need only the help of Allaah." It may be noted that in the battle of Badr Muslims were 1/3 of the numbers of the disbelievers. Being the first battle in its history, it (battle of Badr) was the decider of the fate of Islam. It was a great test from Allaah. Still in that crucial time and situation the Prophet of Islam did not break the given promise. 34 obligatory on a person, or taking a return for doing a job not doing which is obligatory on a person, is what bribe is.
See 51 AL-BAHR AL-MUHIT 533, cited in 5 MA'RIFUL QUR'AN 409.

33 Qur'an, 16:96.

34 Al-Qassam English Forum, Characteristics of Our Beloved Prophet-Fulfillment of Promises, available at http://www. almoltaqa.ps/english/showthread.php?p=42640 (last visited on Nov. 9, 2009). 


\section{Safwan's Case}

Safwan was a mortal enemy of Islam until after the battle of Hunayn and at-Tai' $\mathrm{f}$. After the conquest of Makkah his wife became a Muslim, but he chose to flee. His paternal cousin, Wahb bin Umayr, a converted Muslim went to the Prophet and told him about Safwan. The Prophet gave him his cloak as a token of his safety. Convinced by this, Safwan came to the Prophet, who was friendly with him in spite of his continued refusal to accept Islam. 35

\section{B. Treaty Obligations in Particular}

\section{Treaty of Hudaibiyah and the Case of Abu Jandal}

In the Hijrah year 6, the Prophet and his Companions started for Makkah to perform 'Umrah.' On the way at Hudaibiyah they halted in the face of opposition from the disbelievers of Makkah who wanted the Muslims to go back without performance of this religious duty. At this ultimatum both sides agreed to enter into a treaty. This is known as the Treaty of Hudaibiyah, which included the following terms and conditions:

In your name, $\mathrm{O}$ Allaah. These are the terms of the truce between Muhammad, the son of Abdullah and Suhayl, the son of Amr (of Mecca).

Both parties have agreed to lay down the burden of war for ten years. During this time, each party shall be safe, and neither shall injure the other; no secret damage shall be inflicted, but uprightness and honor shall prevail between them.

The Muslims shall return this year without performing Umrah (the pilgrimage). In the coming year, you may enter it with your companions, staying therein for three days, bearing no arms except the arms of the traveler, with swords remaining in their sheaths.

If a Quraysh person comes to Muhammad (i.e., after accepting Islam) without the permission of his guardian, Muhammad shall return him to them, but if one of the Muhammad's people come to the Quraysh, he shall not be returned.

Whoever wishes to enter into covenant with Muhammad can do so, and whoever wishes to enter into covenant with the Quraysh can do so.36

\footnotetext{
35 For details on Al Muwatta Hadith 28.44, see Safwan Ibn Umayya, available at http://en.wikipedia.org/wiki/ Safwan_ibn_Umayya (last visited on Nov. 9, 2009).

36 Treaty of Hudaibiyah (628 A.D.), available at http://www.cyberistan.org/islamic/treaty28.html (last visited on Nov. 9, 2010).
} 
Though apparently it was an unfavourable and humiliating treaty to the Muslims, the Prophet accepted it by the guidance of Allaah. As soon as he so accepted somehow there appeared Sayyidna Abu Jandal, a Companion of the Prophet, with his legs chained. He was captured by the Makkans who put him in detention and tortured him. After telling his story he requested the Prophet to take him. But bound by the treaty provisions the Prophet refused his appeal and returned him with the people of Makkah. It was a heart-rending scene for the Muslims, but Muhammad still stood by the treaty according to the command of Allaah as contained in the Qur' an discussed above. He gave preference to treaty observance over the personal misfortune and sufferings of his Companion, Abu Jandal. This case comes within the bailiwick of the following command of Allaah about honouring treaty commitments even if it goes against the interest of fellow Muslims. The Qur' an says:

[A]nd if they seek your help in the matter of faith, then, you are bound to help except against a people who have a treaty between you and them. And Allaah is watchful over what you do. 37

\section{Breach of Hudaibiyah Treaty and the Prophet's Reaction}

When the treaty of Hudaibiyah was concluded, some tribes of Makkah joined it as allies- the tribe of Banu Khuza'ah chose to become an ally of the Prophet while the tribe of Banu Bakr chose to be on the side of the Quraysh. Accordingly, the treaty terms and conditions became applicable to the allies in the same way as they applied to the principal parties. By the treaty both sides agreed to a peaceful co-existence for ten years. But within 18 months of the conclusion of the treaty, the Banu Bakr, with the aid of the Quraysh, launched an ambush by night on Banu Khuza' ah. This violated the terms of the peace treaty and at this Allaah declared the termination of the treaty as follows:

[This is] a declaration of immunity (termination of treaty) by Allaah and His Messenger to the idolaters with whom you have a treaty. 38

37 Qur'an, 8:72. The following is the background of this revelation. When the torture and oppression of the disbelievers of Makkah exceeded all limits, Allaah commanded the Prophet and his Companions to migrate from Makkah to Madina. Still some people stayed behind. This created doubt about their true faith (Iman). At this backdrop Allaah ordained that Muslims would inherit between themselves only, meaning non-Muslims who were related by blood with Muslims would not inherit their property after their death and vice versa. This prohibition applied even to selfprofessed Muslims who clung to Makkah despite the command of Allaah. However, Allaah offered one privilege to them that if disbelievers of Makkah attacked them because of their faith, Muslims must help them against disbelievers provided there was no no-war treaty between Muslims and the disbelievers. In other words, Muslims must not help their fellow Muslims in breach of any no-war pact. See MuHammad SHAFI, 4 MA'RIFUL QuR'An 289 (M. SHAMIM ENG. TRANS., 1999). 
Accordingly, the Prophet made preparations to take over Makkaah. By that time the Muslims were militarily far stronger than the Makkans. In order to keep casualties to a minimum, the Prophet made secret preparations and marched for Makkah on 10 Ramadan of Hijri year 8. He conquered Makkah bloodlessly. In this way the Prophet addressed the breach of pacta doctrine.

It is worth mentioning that the Prophet did not take any revenge against the people who were his enemies, especially the Quraysh who broke the treaty themselves. Rather he forgave them all and said, "Today, I say to you exactly what was said by (Prophet) Yusuf (Joseph) to his brothers at the time when they had reached him in Egypt with their parents: This day, there is no blame on you." 39 As it is forbidden to fight or kill during the 'sacred months' (Zhul-Hijja, Muharram, Safar and Rabiul Awal), the Prophet granted them four months respite after which they had three options- either to leave the Arabian peninsula or to accept Islam and lead a pious life. Otherwise they had to face war. The Qur' an laid down the command as follows:

So, when the sacred months expire, kill the Mushriks wherever you find them. And catch them and besiege them and sit in ambush for them everywhere. Then, if they repent and establish salah (prayers) and pay zakat (obligatory charity), leave their way (do not disturb them). Surely, Allaah is most Forgiving, Very Merciful.40

\section{Other Peace Treaties}

Apart from the Hudaibiyah Treaty there were some other treaties between Muslims and some particular disbeliever-tribes of Makkah (other than the Quraysh) for a specific period of time, such as Banu Kinanah and Banu Mudlaj. Because ever since those tribes abided by the treaties, the Prophet, directed by Allaah, fulfilled the remaining term of the treaties, which was nine months:

Except those of the Mushriks with whom you have a treaty, and they have abated nothing of your rights and backed no one against you, so then, fulfill the treaty with them up to their term. Surely, Allaah loves the God-fearing.41

There were people with whom Muslims had treaties with no fixed time-limit. As well, there were people who had no treaty-based relation with the Muslims. For these two categories of people Allaah offered a respite of four months. During this time they could consider accepting Islam and living as Muslims with equal status with others; or leave

\footnotetext{
39 Shafi, supra note 37 , at 305-306.

40 Qur'an, 9:5.

41 Id. 9:4.
} 
the Arabian peninsula; or face war with the Muslims. The Qur' an says:

So, move in the land freely for four months, and be sure that you can never defeat Allaah and that Allaah is about to disgrace the disbelievers (with calamities on earth and punishment in the hereafter). ${ }^{42}$

\section{Conclusion}

From the above discussion it is found that the pacta doctrine is of divine origin in the Islamic legal tradition. It is an obligatory command of Allaah and a sacred practice (Sunnah) of the Prophet (peace be upon him). It is part and parcel of the faith (Iman) of the Muslims. Allaah has commanded them to fulfill their promises and thereby to uphold their faith and to render justice to others. Otherwise, punishment will follow both in this world and hereafter. So believers must keep their promises of all sorts including international treaties unless they are against Shari'ah law. The Prophet has set the best examples of keeping promises by truly acting upon the command of Allaah. He honoured treaties with other nations even at the expense of strategic disadvantages, humiliation and perils to his community (Ummah). He kept his treaties until their agreed time-limit had expired despite his and Muslim community's unquestionable power and authority after the conquest of Makkaah. He granted the Quraysh, who violated the Hudaibiyah treaty, kindness and offered respite for the 'sacred months' (four months in length). He could have killed them, expelled them from Makkaah straight away or taken any other retaliatory measures, but he did not. He forgave them and granted them time to accept the life-style of Muslims, failing which they had the option to emigrate outside of Arabian peninsula. He did not impose the religion of Islam on them. He gave them a freedom to make their own choice. He kept a door to acceptance of Islam open to them. And this was not prompted with any selfish interest, rather with his concern for their salvation in the afterlife. And that was the sole purpose he came as the last Prophet for the mankind.

As a consequene, it may be said that Islam perceives the pacta doctrine as a sacred principle of faith, religion and law. The principle has emanated from Allaah and the Prophet has implemented it in the real life situation setting examples for the Muslims and for the people at large. The objective of this principle is to attain Allaah's pleasure by keeping both promises given to Him to obey Him and promises/agreements/ 
treaties made with people. This objective is far beyond the mundane objective of social good as perceived by the West. Islam seeks social peace and security as a corollary of obeying this command of Allaah. In that case, Allaah's pleasure is the objective, respecting the principle of pacta is a means to gain that objective and, peace and security in the worldly life is a consequential reward for working toward this objective. 
